\title{
Newcastle Disease Virus
}

National Cancer Institute

\section{Source}

National Cancer Institute. Newcastle Disease Virus. NCI Thesaurus. Code C93023.

A neg ative-stranded RNA virus that infects birds. It is the type strain for avian paramyxoviruses. 